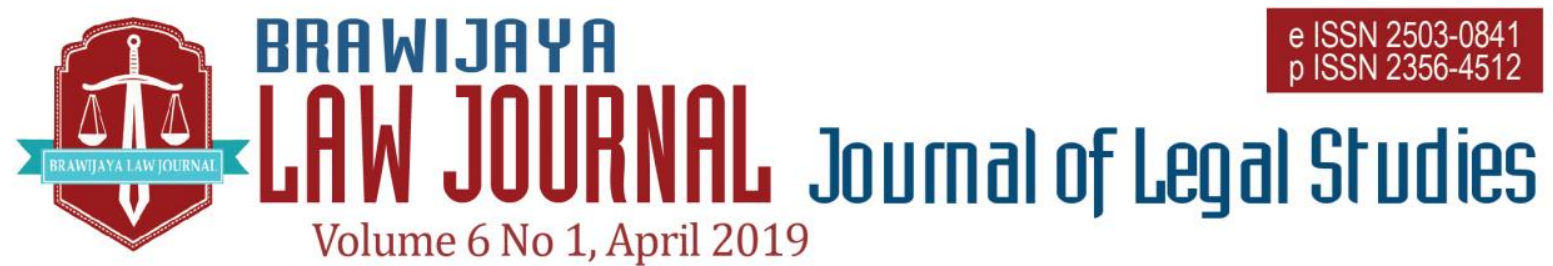

Nationally Accredited No. 30/E/KPT/2018 Dated 24th October 2018

This work is licensed under a Creative Commons Attribution-NonCommercial 4.0 International License

\title{
The Supremacy of the Dispute Settlement Mechanism (DSM) under the World Trade Organization (WTO)
}

\section{Gusti Ngurah Parikesit Widiatedja ${ }^{a}$}

${ }^{a}$ Faculty of Law Udayana University

Jl. Pulau Bali No.1 Denpasar

Email: ngurahparikesit@gmail.com

Submitted : 2019-01-16 | Accepted : 2019-03-25

\begin{abstract}
The existence of inequality and poverty in some countries doubted the contribution of the WTO. The overwhelming spirit of national interest through the imposition of discriminatory and protective measures has deteriorated the WTO. Given its role for enforcing trade commitments, the dispute settlement mechanism is crucial to save the future of WTO. This paper aims to analyse the existence of the dispute settlement mechanism of WTO, whether it is still supreme in upholding the vision of trade liberalization. This paper argues that the supremacy of this mechanism has ensured the future of WTO by looking at two parameters. Firstly, it has a ruled-based character with a high level of legalism. Next, by looking at the decision of the Panel and the Appellate Body, the dispute settlement mechanism has effectively controlled the overwhelming spirit of national interest. This mechanism shows its supremacy by limiting the capacity of the WTO member states to impose discriminatory and protective measures, particularly related to public morals exception and cultural concern.
\end{abstract}

Keywords: supremacy; dispute settlement mechanism; world trade organization.

\section{INTRODUCTION}

The existence of World Trade Organization ('WTO') that promotes trade liberalization has been doubted as the inequality and poverty occur in some countries. ${ }^{1}$ Muhammad Yunus, the Nobel Peace Prize's winner, denoted that the inequality of income was undeniable, pointing out 40 percent of population controlled 94 percent of the global income when 60 percent people relished only six percent of the income. ${ }^{2}$ Stiglitz then revealed that the implementation of trade liberalization without preparing safety nets, with lacking reciprocity and backing on the
I Gusti Ngurah Parikesit Widiatedja, Kebijakan Liberalisasi Pariwisata: Konstruksi Konsep, Ragam Masalah, dan Alternatif Solusi (Udayana University Press, 2011) 34.
2 Muhammad Yunus, 'Nobel Lecture', 10 December 2006 <http://nobelprize.org/nobel_prizes/peace/laureat es/2006/yunus-lecture-en.html>. 
part of developed economies, may lead to an upsurge in poverty. ${ }^{3}$

The following empirical studies showed how the two basic problems above still existed, making the WTO difficult to realize world's prosperity. Specifically, wage's gap was still unresolved in countries, for example, Indonesia, ${ }^{4}$ Colombia, ${ }^{5}$ and India. ${ }^{6}$ Besides, in 2015, the United Nations Development Programme ('UNDP') illustrated that between 1990 and 2015, where the global average of extreme poverty reduced from 47 to 14 percent, Sub-Saharan Africa only reduced from 57 to 41 percent. $^{7}$

The poverty rate in Central Asia, Europe and Africa was analysed by the World Bank. ${ }^{8}$ In Europe and Central Asia, from 272.4 millions of total population with 0.7 percent the growth of population, less than two percent population living under $\$ 1.25$ per day. ${ }^{9}$ Conversely, in Africa, from 936.3 million total population with 2.7 percent the growth of population, 46.8 percent Population living under $\$ 1.25$ per day. ${ }^{10}$

There has been a constant protest over WTO meeting across the globe, criticizing the urgency of WTO for reducing poverty and inequality. For instance, when Indonesia

3 Joseph Stiglitz, 'Addressing Developing Country Priorities and Needs in the Millennium Round' in Roger B Porter and Pierre Sauve (eds), Seattle, the WTO and the Future of the Multilateral Trading System (Harvard University Press, 2000) 55.

4 Ibid 69.

5 Adrian Wood, 'Openness and Wage Inequality in Developing Countries: The LatinAmerican Challenge to East Conventional Wisdom' (1997) 11(1) World Bank Economic Review 57, see also Orazio Attanasio, Pinelopi Goldberg and Nina Pavcnik, 'Trade Reforms and Wage Inequality in Colombia' (2004) 74 Journal of Development Economics 366.

6 The Organization for Economic Co-operation and Development, Special Focus: Inequality in Emerging Economies (EEs) (OECD, 2011) 53.

7 United Nations Development Programme, Human Development Report 2015 (United Nations,2015) 58.
(Bali) was a host of WTO annual meeting in 2013, protesters revealed their critics over the application of trade liberalization. They claimed that Bali Package was meaningless for Indonesia, and only downgraded civil servants and farmers, making Indonesia as a prey of trade measures. ${ }^{11}$

The overwhelming spirit of national interest also put WTO at risk, leading to the failures to issue trade deals. ${ }^{12}$ For example, the deadlock of the Doha Development Agenda ('DDA') due to the unsettled discrepancy between developing countries and developed countries on issues associating to, among other things, agriculture and trade remedies. ${ }^{13}$ This deadlock has triggered member states to find other trade negotiations (such as Preferential Trade Agreements (PTAs) to continue their economic cooperation, particularly to intensify trade and investment flows.

Some countries' local policies also deteriorate the abovementioned fact. Specifically, some EU's states increased trade limitation to cross-border mergers, to

8 World Bank, The World Bank Group A to Z (World Bank, 2016) 52.

9 Ibid

10 Ibid.

11 Ni Komang Erviani and Tassia Sipahutar, 'AntiWTO activists make their move' on The Jakarta Post (Online) (3 December 2013), <http://www.thejakartapost.com/news/2013/12/03 /anti-wto-activists-make-their-move.html>

12 I Gusti Ngurah Parikesit Widiatedja and I Gusti Ngurah Wairocana, 'The Rise of the Spirit of National Interest and the Existence of World Trade Organization Agreement: A Case Study of Indonesia' (2017) 4(2) Padjajaran Journal of Law 319.

13 BBC News (Online), World Trade Talks End in Collapse (29 July 2008), <http://news.bbc.co.uk/2/hi/business/7531099.stm $>$. 
prevent the loss of national vanity and jobs. ${ }^{14}$ In the same way, the president of USA, Donald J Trump conducted anti-dumping measures to unilaterally convict any countries whose products were harming local producers. ${ }^{15}$ Indonesia imposed several nontariff barriers (NTBs), such as export restrictions and import licenses although it had reduced its tariffs. ${ }^{16}$ Finally, some countries imposed trade measures for guarding what they have assumed as local cultures that may fall within the scope of 'inefficient protectionism'. ${ }^{17}$

Despite international courts may be unable to ask member states for respecting their decisions, ${ }^{18}$ a dispute settlement mechanism ('DSM') has a salient role for upholding the commitments agreed under trade negotiations. ${ }^{19}$ Any trade agreements would not have been agreed without having the DSM. ${ }^{20}$ Matsushita explained that trade agreements required trade rules and enforcement because trade agreements would not be able to avoid and eliminate the states' trend to deviate from market access commitments. ${ }^{21}$

14 Raymond J. Ahearn, Europe: Rising Economic Nationalism? (CRS Report for Congress, 2006) $\langle$ http://research.policyarchive.org/4378.pdf $>$.

15 World Policy, Trump and Trade Bilateralism on World Policy (Online) (12 January 2017), <http://www.worldpolicy.org/blog/2017/01/12/tru mp-and-trade-bilateralism $>$.

16 Margit Molnar and Molly Lesher, 'Indonesia' in Organization for Economic Cooperation and Development, Globalisation and Emerging Economies: Brazil, Russia, India, Indonesia, China, and South Africa (OECD, 2008) 334.

17 Krista Boryskavich and Aaron Bowler, 'Hollywood North: Tax Incentives and the Film Industry in Canada' (2002) 2 Asper Review of International Business and Trade Law 25, 26.

18 Karen J Alter, The New Terrain of International Law: Courts, Politics, Rights (Princeton University Press, 2014) 32.

19 World Trade Organisation Secretariat, World Trade Report 2007: Six Decades of Multilateral Co-operation - What Have We Learned? (WTO, 2007) 155.

20 Ibid.
Amid the gloomy picture of the future of WTO, the existence of the DSM consisting of the Dispute Settlement Body ('DSB') and the Appellate Body ('AB') has saved WTO's future. The DSM WTO has adjudicated 405 disputes, putting it as the most productive of all international dispute settlement mechanism. ${ }^{22}$ Some experts have praised the productivity of the DSM WTO. Zimmermann (2005) denoted that the DSB WTO has effectively implemented the accurate time limits throughout the process of dispute settlement. ${ }^{23}$ Lockhart and Voon (2005) stated that the WTO appellate review was effective, that should be a role model in the development of international trade law. ${ }^{24}$ Similarly, Guzman and Pauwelyn (2012) concluded that the DSM WTO was one of the most remarkable of WTO's feature. ${ }^{25}$

DSM WTO whether it falls within the scope of a legal-character or just a politicalcharacter. This paper aims to analyse the existence of the DSM WTO, whether it is still supreme in upholding the vision of trade liberalization in realizing world's prosperity. The questionable contribution of WTO in

21 Mitsuo Matsushita (et al), The World Trade Organization: Law, Practice, and Policy (Oxford University Press $3^{\text {rd }}$ ed, 2003) 8.

22 Peter Van den Bossche, The Law and Policy of the World Trade Organization (Cambridge University Press, 2010) 169.

23 Thomas A. Zimmermann, 'WTO Dispute Settlement at Ten: Evolution, Experiences \&Evaluation' (2005) 60 The Swiss Review of International Economic Relations 53.

24 John Lockhart and Tania Voon, 'Review of the Appellate Review in the WTO Dispute Settlement System' (2005) 6 Melbourne Journal of International Law 476.

25 Andrew T.Guzman and Joost H.B. Pauwelyn, International Trade Law (Wolters Kluwer, $2^{\text {nd }}$ ed., 2012) 127, See also Nicolette Butler, 'In Search of a Model for the Reform of International Investment Dispute Resolution: An Analysis of Existing International and Regional Dispute Settlement Mechanisms' in Jean E. Kalicki and Anna Joubin-bret (eds), Reshaping the InvestorState Dispute Settlement System: Journeys for the 21st Century (Nijhoff, 2015) 355.

62 Widiatedja - The Supremacy of the Dispute Settlement Mechanism (DSM)... 
reducing poverty and inequality, along with the escalation of the spirit of national interest may put the future of WTO at risk. This paper, however, argues that the existence of the DSM WTO has ensured the future of WTO by looking at two parameters. Firstly, it will analyse the character of the of DSM. Secondly, it will analyse how the Panel and the Appellate Body, through their decisions, have responded the trend of the rise of national interest, which can be traced through discriminatory and protective measures of the WTO member states.

This paper starts by explaining the DSM WTO, consisting of the history of the DSM under the GATT 1947 and the current procedure of the DSM WTO, including Indonesia's participation. It then turns to analyse the character of the DSM WTO whether it falls within the scope of political or legal character of DSM. Finally, this paper analyses the decision of the Panel and the Appellate Body in responding the rise of the spirit of national interest through the imposition of protective and discriminatory measures.

\section{LEGAL MATERIAL AND METHODS}

This paper is normative legal research, which based on primary on international agreement related to the dispute settlement mechanism and the decision of the Panel and Appellate Body, secondary one included references from books, journal articles, internet resource such as news and other

26 General Agreement on Tariffs and Trade 1994, Apr. 15, 1994, Marrakesh Agreement Establishing the World Trade Organization, Annex 1A, 1867 U.N.T.S. 187, 33 I.L.M. 1153 (1994) art. XXII [GATT 1994].

27 Ibid art. XXIII.

28 Leslie JOHNS, Strengthening International Courts: The Hidden Costs of Legalization (University of Michigan Press, 2015) 135. documents having correlation with the paper issues. This paper use legal interpretation to analysis the data.

\section{RESULT AND DISCUSSION}

\section{The Dispute Settlement Mechanism under the WTO}

\section{a. The dispute settlement mechanism under the GATT}

The existence of the DSM GATT 1947 coloured the history of the DSM WTO. Initially, contracting parties could start the process of dispute settlement through submitting consultation. ${ }^{26}$ A contracting party could demand this practice if it deemed other parties had been unsuccessful to implement GATT's obligations or 'nonviolation nullification or impairment of the benefits of GATT'. ${ }^{27}$ Contracting parties could undertake consultation with or without the presence of a mediator or working party. ${ }^{28}$ If the consultations was unsuccessful to settle disputes, the working party that covered representatives from all related parties, mostly the parties to the dispute, ${ }^{29}$ had to 'promptly investigate' and submitted a report with recommendations, for adoption by the contracting parties. ${ }^{30}$

The panel then substituted working parties' role to settle a dispute among GATT contracting parties. If a particular party was displeased with the result, it could propose the formation of an ad hoc panel to enact a legal recommendation on the designated matter. The panel consisted of three or five

29 The World Trade Organization, Historic Development of the WTO Dispute Settlement System <https://www.wto.org/english/tratop_e/dispu_e/di sp_settlement_cbt_e/c2s1p1_e.htm> [WTO 2].

30 Amelia Porges and John H. Jackson, 'The WTO and the New Dispute Settlement' (1994) 88 American Society of International Law 131-139. 
autonomous professionals (who were not essentially jurists) who had no connection to the dispute's parties. ${ }^{31}$ A respondent party, however, could postpone or block the panel's establishment. ${ }^{32}$ With a neutral calculation, the panel then enacted a report that was binding only after the GATT Council's approval. ${ }^{33}$ Again, the respondent party had been granted a veto right to block the panel report's adoption.

The presence of a veto right that enables contracting parties to block the establishment of the panel and the report of the panel shows the political style of the DSM GATT. There is no 'automatic' right to avoid this blocking scheme from happening. Therefore, according to Hudec (1975), the DSM that ended up with a GATT ruling is a 'punch that will not hit anyone'. ${ }^{34}$

\section{b. The Dispute Settlement Mechanism under WTO}

The primary goal of the WTO DSM is to promptly resolve the WTO members' disputes concerning the particular rights and obligations of the WTO members. ${ }^{35}$ According to Article 3.3 of the DSU, the prompt and efficient of such quarrels is crucial to the effective WTO's function and the balance between the member's rights and obligations. ${ }^{36}$ The current mechanism of the DSM WTO consists four stages:

31 Nellie Munin, 'The Evolution of Dispute Settlement Provisions in Israel's PTAs: Is There a Global Lesson?' (2010) 44(2) Journal of World Trade 388.

32 Marc L. Busch, 'Democracy, Consultation, and the Panelling of Disputes under GATT' (2000) 44(4) The Journal of Conflict Resolution 428.

33 WTO 2, above n 24.

34 Robert E. Hudec, The GATT Legal System and World Trade Diplomacy (Praeger, 1975) 219.

35 Peter Van den Bossche, The Law and Policy of the World Trade Organization (Cambridge University Press, 2010) 169.

36 Dispute Settlement Rules: Understanding on Rules and Procedures Governing the Settlement of Disputes, Marrakesh Agreement Establishing the consultations, panel report, Appellate Body report ( $\mathrm{AB}$ report), and $\mathrm{DSB}$ adoption.

The DSM WTO is commenced when a member proposes consultations with the other member states. ${ }^{37}$ The responding member has to answer to this proposal in ten days, and then it has to come into good faith consultations in 30 days after getting the proposal. ${ }^{38}$ If the consultation is unsuccessful in 60 days, a panel is created. ${ }^{39}$ Except the members to a dispute agree otherwise, the panel consists three or five panellists (who are not essentially jurists) nominated from the list of Secretariat. ${ }^{40}$ Although the panellists act on behalf of their individual capabilities, the point that the quarrelling members have to agree on the panellists can affect their position. ${ }^{41}$ Next, the disputing members explain their proposal to the panel, and then, the panel enacts final report, containing recommendations and conclusion. ${ }^{42}$ The Dispute Settlement Body (DSB) accepts this report within 60 days, unless if there is a consent against adoption. ${ }^{43}$

If the disputing members are disagreeing with the report of panel, the Appellate Body ('AB') hands over the case. Different than the panel, the $\mathrm{AB}$ has a permanent configuration, encompassing seven independent legal professionals ${ }^{44}$ who serve for a four-year term, renewable only

World Trade Organization, Annex 2, 1869 U.N.T.S. 401, 33 I.L.M. 1226 (1994) art 3.3 [DSU].

37 Nguyen Tan Son, 'Towards A Compatible Interaction between Dispute Settlement under the WTO and Regional Trade Agreements' (2008) 5 Macquarie Journal of Business Law 113-135.

38 DSU above n 31, art. 4.3.

39 Ibid art. 4.7 and 4.8.

40 Ibid art. 8.4 and 8.5.

41 Bernhard ZANGL, 'Judicialization Matters! A Comparison of Dispute Settlement Under GATT and the WTO' (2008) 52(4) International Studies Quarterly 825-854.

42 DSU above n 31, art. 16.4.

43 Ibid art. 16.4.

44 Ibid art. 17.1. 
once. 45 The recommendations and conclusions of the $\mathrm{AB}$ report are automatically adopted by the DSB, except the DSB rules by consensus not to follow the $\mathrm{AB}$ report. ${ }^{46}$ The application of the recommendations (either the panel or the Appellate Body) has to be executed for 'a reasonable period of time'. ${ }^{47}$ When the responding member is disobey the final decision, the complaining member can carry out temporary trade retaliation, ${ }^{48}$ and the extent of this measure is the arbitration's object. $^{49}$

\section{c. Indonesia's Participation}

Under the DSM WTO, Indonesia was embroiled in some disputes. In 1995, as a third party, Indonesia participated in BrazilDesiccated Coconut, complaining a countervailing duty of Brazil executed on desiccated coconut and coconut milk imported from the Philippines. ${ }^{50}$ In Indonesia - Certain Measures Affecting the Automobile Industry in 1996, The EU, Japan, and the USA filled a complaint to Indonesia concerning the program of National Car. ${ }^{51}$ They accused that the exception from luxury taxes and customs duties on imports of 'national vehicles' and machineries thereof, violated of Indonesia's responsibilities under Articles I and III of GATT 1994, Article 2 of the TRIMs Agreement and Article 5(c) of the

45 Louise Johannesson and Petros C. Mavroidis, 'The WTO Dispute Settlement System 1995-2016: A Data Set and Its Descriptive Statistics' (2017) 51(3) Journal of World Trade 357-408.

46 DSU above n 31, art. 17.4.

47 Ibid art. 21.3.

48 Ibid art. 22.

49 Ibid art. 22.7.

50 WTO Appellate Body Report, "Brazil - Measures Affecting Desiccated Coconut" (WTO Doc WT/DS22/AB/R, 20 March 1997) 167.

51 WTO Panel Report, "Indonesia - Certain Measures Affecting the Automobile Industry"(WTO DocWT/DS54/R，WT/DS55/R, WT/DS59/R, WT/DS64/R, Corr. 1,Corr .2, Corr. 3, and Corr.4, 23 July 1998) 2201.
Agreement on Subsidies and Countervailing Measures (SCM Agreement). ${ }^{52}$ The Panel then supported this accusation, ruling Indonesia derogated those agreements. ${ }^{53}$

The program of national car was an instance how Indonesia had promoted national interest to deviate from the WTO agreement. Nevertheless, this interest was not essentially the national interest, but somewhat the interest of family elite's by considering at the parties who were embroiled in this discriminatory program. Specifically, one of president's children was the chief of corporation that was given a license to import 'national car' from Korea without requiring an duty to pay what has been called (at that time) as the obligatory 35 percent lavish tax on cars. ${ }^{54}$

Since 1998, Indonesia has been involving in the WTO dispute as a respondent for 10 disputes, a complainant for 10 disputes and a third party for around 17 disputes. ${ }^{55}$ For instance, in US - Clove Cigarettes, promoting what it called as national interest, Indonesia filled a lawsuit, protesting the US's ban on clove cigarettes from Indonesia, but permitting the local cigarettes' production and sale. ${ }^{56}$ The $\mathrm{AB}$ then upheld this complaint, ruling the ban deviated of national treatment principle under the agreement of Technical Barriers to Trade ('TBT'). 57

52 Ibid.

53 Ibid.

54 Thomas Lindblad, 'The Political Economy of Recovery in Indonesia' in Jolle Demmers (etal), Good Governance in the Era of Global Neoliberalism (Taylor and Francis, 2004) 219.

55 WTO, 'Dispute Settlement: Disputes by country/territory',

<https://www.wto.org/english/tratop_e/dispu_e/di spu_by_country_e.htm>.

56 Appellate Body Report, 'United States - Measures Affecting the Production and Sale of Clove Cigarettes' (WT/DS406/AB/R, adopted 24 April 2012, DSR 2012: XI) 5751

57 Ibid. 
For Indonesia, the decision of WTO Dispute Settlement was relatively objective. The national car case showed how the domestic policy of Indonesia had conlicted the WTO agreement so that it was sensible if the Appellate Body then nullified this policy. On the other hand, Indonesia gained a significant benefit when the Appellate Body annulled the domestic policy of the US that prohibited clove cigarettes from Indonesia, but allowing the existence of local cigarettes, leading to the violation of national treatment principle.

\section{Why the Dispute Settlement Mechanism WTO is still Supreme?}

\section{a. The Ruled-Based Mechanism of the WTO Dispute Settlement}

Some experts classified the character of the DSM in trade agreements. Munin (2010) divided the DSM into political or legal character. ${ }^{58}$ The following structures reflect the political character of the DSM: The absence of final decision or simply political mechanism; the decision-making mechanism is determined by consensus; and the lack of comprehensive legal stage. ${ }^{59}$ In contrast, if the decision of the DSM is binding, and a third authority is dynamically involved (subject to parties' consensus) to settle the dispute, the legal character of the DSM has been used. ${ }^{60}$

Jo and Namgung (2012) categorized the level of legalism of the DSM into 'low', 'medium', and 'high'. 61 'Low' reflects to a

\footnotetext{
58 Munin, above n 30, 393.

59 Ibid.

60 Ibid.

61 Hyeran J and Hyun Namgung, 'Dispute Settlement Mechanisms in Preferential Trade Agreements: Democracy, Boilerplates, and the Multilateral Trade Regime' (2012) 56(6) Journal of Conflict Resolution 1041.

62 Ibid.

63 Ibid.

64 Ibid, 1044.
}

condition wherein agreements do not permit the existence of third-party or there has been a non-binding nature third-party's decision. ${ }^{62}$ Afterwards, 'medium' reflects to the binding nature of third-party's decision. ${ }^{63}$ Finally, 'high' legalism is taken place through the presence of permanent standing tribunals in the DSM. ${ }^{64}$

The DSM WTO has a legal character with high level of legalism. Firstly, the existence of $\mathrm{AB}$ that is a permanent and independent body, encompassing legal experts who serve with fixed terms. The AB also has a more functional and administrative autonomy likes budget and legal personality. Islam (2006) analysed how the DSM WTO implemented a rule-oriented process through the presence of the "covered agreements" as the basis of law, decreasing the discrepancies of power, protecting the legitimate interests of member, and preventing the abusive exercise of rights. ${ }^{65}$

Zangl (2008) then examined how the panel has been required to put appropriate legal reasoning as, otherwise, its report will be negated by the AB. ${ }^{66}$ Furthermore, the DSM WTO was able to correct some weaknesses of the DSM GATT, ${ }^{67}$ changing the political character of the DSM GATT into a more legal character. Finally, Bown (2005) acclaimed how the DSM WTO had removed the blocking mechanism that allowed members to avoid the commencement of a dispute, the establishment of the panel, and the adoption of the panel report. ${ }^{68}$

65 M. Rafiqul Islam, International Trade Law of the WTO (Oxford University Press, 2006) 428.

66 Bernhard Zangl, 'Judicialization Matters! A Comparison of Dispute Settlement under GATT and the WTO' (2008) 52(4) International Studies Quarterly 825.

67 John H Jackson, The World Trading System: Law and Policy of International Economic Relations (MIT Press, 1997) 117.

68 Chad P. Bown, 'Participation in WTO Dispute Settlement: Complainants, Interested Parties and 
The next rationales for the DSM WTO is the existence of 'inherent powers', 69 including the authority to administer the proceedings to the degree essential to accomplish their adjudicative role. ${ }^{70} \mathrm{By}$ having this power, tribunals could freely determine what evidence to concede, and how to weigh that evidence. ${ }^{71}$ Besides, under the DSM WTO, whenever a member states intend to fill a complaint against another WTO member states, it can request tribunal proceedings without the defending party's consent. ${ }^{72}$ This mechanism differs from typical international tribunal where states can only be sued before an international tribunal if they have consented to the tribunal's jurisdiction. $^{73}$

The legal character of the DSM WTO has put all its member states equally, particularly in the participation under the DSM WTO. Specifically, it has attracted developing countries' participation. Brazil (30 complaints), India (23 complaints), Argentina (21 complaints), Mexico (21 complaints), and Indonesia (10 complaints) are among the recurrent users of the DSM. ${ }^{74}$ China (that joined the WTO in 2001), has

Free Riders' (2005) 19(2) The World Bank Economic Review 293.

69 Andrew Mitchell and David Heaton, 'The Inherent Jurisdiction of WTO Tribunals: The Select Application of Public International Law Required by the Judicial Function' (2010) 31 Michigan Journal of International Law 561.

70 Michelle Grando, Evidence, Proof and FactFinding in WTO Dispute Settlement (Oxford University Press, 2009) 54.

71 Tania Voon, 'Evidentiary Challenges for Public Health Regulation in International Trade and Investment Law' (2015) 18 Journal of International Economic Law 800.

72 David Unterhalter, 'What Makes the WTO Dispute Settlement Procedure Particular: Lessons to be Learned for the Settlement of International Disputes in General?' in Rüdiger Wolfrum and Ina Gätzschmann (eds), International Dispute Settlement:Room for Innovations? (Springer,2013)6.

73 Ibid. filed some important cases against both the European Union and the United States. ${ }^{75}$ Interestingly, developing economies magnificently beat economic superpower states in some WTO disputes. For example, US-Underwear, a complaint by Costa Rica; US - Clove Cigarettes, a complaint by Indonesia; and even more so US - Gambling, a complaint by Antigua, which has a population only 67,000 .

Although the DSM WTO seems ideal, there has been a weakness over this process. The legalisation of this mechanism requires arduous financial and human resources that are often deficient in developing economies. Besides, because of the inequalities of market power, the retaliatory remedy looks not to be an effective process to any member states, ${ }^{76}$ excluding the powerful one, such as the European Union and the United States. ${ }^{77}$

\section{b. The Decision Can Effectively Control the Overwhelming Spirit of National Interest}

1) Discriminatory Measures by Using Public Morals Exception

74 This can be traced through Map of Disputes Between WTO Members, <https://www.wto.org/english/tratop_e/dispu_e/di spu_maps_e.htm>

75 Gary N. Horlick and Katherine fennell, 'WTO Dispute Settlement from the Perspective of Developing Countries' in Yong-Shik Lee, Gary N. Horlick, Won-Mog Choi and Tomer Broude (eds), Law and Development Perspective on International Trade Law: The Law and Development Institute (Cambridge University Press, 2011)164.

76 See, for example, Chad P. Bown, 'On the Economic Success of GATT/WTO Dispute Settlement' (2004) 86 The Review of Economics and Statistica 811.

77 William J. Davey, 'Dispute Settlement in the WTO and RTAs: A Comment' in Lorand Bartels and Federico Ortino (eds), Regional Trade Agreements and the WTO Legal System (Oxford University Press, 2006) 355. 
As mentioned earlier in the introductory section, the overwhelming spirit of national interest has put WTO at risk. The unfinished debate between developing countries and developed countries has led to the deadlock of the DDA. Many WTO member states also impose discriminatory measures to promote what they have been regarded as a national interest. Historically, during the 1930s Great Depression, many states conducted discriminatory trade policies, causing to political and economic crises. ${ }^{78}$ This fact was one of the major contributing aspects of the World War II. ${ }^{79}$ Therefore, when today's discriminatory practices are not properly handled, it would harm the future of the WTO and international trade governance.

The preamble of the WTO expressly stated that the primary goal of the multilateral trading system is 'the elimination of discriminatory treatment in international trade relations' ${ }^{80}$ To elaborate this goal, the Appellate Body in EC - Banana III held that the nature of the non-discrimination duty is that 'like products should be treated equally, irrespective of their origin'. ${ }^{81}$

Due to its vague meaning, the use of public morals exception can be employed as a justification to impose discriminatory

78 Van Den Bossche, Above n 21, 321.

79 Ibid.

80 Andrew D Mitchell and Nicolas JS Lockhart, 'Ensuring Compliance between a Bilateral PTA and the WTO' in SisiraJayasuria, Donald MacLaren and Gary Magee (eds), Negotiating a Preferential Trading Agreement: Issues, Constraints and Practical Options (Edward Elgar, 2009) 235.

81 Appellate Body Report, European Communities Regime for the Importation, Sale and Distribution of Bananas (WT/DS27/AB/R,25 September 1997) Para 190.

82 I Gusti Ngurah Parikesit Widiatedja, Can Indonesia Invoke Public Morals Exception under the World Trade Organization (WTO) for Prohibiting Cross-Border Gambling? (2018) 7(2) Yustisia 261, 263. measures through trade barriers that they assumed were in public morals' interest. ${ }^{82}$ Specifically, Canada explicitly showed its ban for child pornography, and materials considered obscene, treasonous, or seditious. ${ }^{83}$ Colombia banned pornographic material containing minors. ${ }^{84}$ In the same way, South Korea and Mozambique forbid pornographic materials despite it did not expressly mentioned what particular type of pornography was. ${ }^{85}$

The following disputes, however, shows how the decision of the Panel and the Appellate Body has successfully controlled the discriminatory measure of WTO member states by employing public morals exception. All these measures were eventually classified as 'arbitrary or unjustifiable discrimination' or a 'disguised restriction on international trade' following Article XX GATT 1994.

In US - Shrimp, U.S shrimp trawlers was required by Endangered Species Act to apply 'turtle excluder devices' (TEDs) that enabled shrimp to go through to the rear of the net while avoiding turtle from doing so. ${ }^{86}$ Despite this measure was needed to 'the conservation exhaustible natural resources', the $\mathrm{AB}$ rules that such measure was 'unjustifiable discrimination.' 87 The rationale of this decision was that this

83 WTO Secretariat, 'Report of the WTO Secretariat on the Trade Policy Review of Canada' (WT/TPR/S/53, 19 November 1998) para 46.

84 WTO Secretariat, 'Report of the WTO Secretariat on the Trade Policy Review of Colombia' (WT/TPR/S/172/Rev.1, 3 April 2007) para 41.

85 WTO Secretariat, 'Report of the WTO Secretariat on the Trade Policy Review of South Korea' (WT/TPR/S/137. 18 August 2004) para 54, and WTO Secretariat, 'Report of the WTO Secretariat on the Trade Policy Review of Mozambique' (WT/TPR/S/79, 21 December 2000) para 33.

86 Appellate Body Report, 'United States - Import Prohibition of Certain Shrimp and Shrimp Products' (WT/DS58/AB/R, 6 November 1998) para 138.

87 Ibid. 
measure stipulated other WTO members to adopt the similar program and enforcement mechanisms as the U.S without seeing their dissimilar situation that may take place in those other members' territory. ${ }^{88}$

In US-Gambling, the panel checked the range of application of the Interstate Horseracing Act ('IHA'). The text of the IHA explained that ' $[a] n$ interstate off-track wager may be accepted by an off-track betting system' when approval was attained from particular organizations. ${ }^{89}$ Simply speaking, the panel and the $\mathrm{AB}$ argued that the IHA permitted domestic service providers, but not foreign providers, to deal remote betting services concerning certain horse races. ${ }^{90}$ As a consequence, the U.S was unable to prove that its measures did not fall within the meaning of 'arbitrary and unjustifiable discrimination'. 91

In EC-Seal Products, both the Panel and the Appellate Body analyzed the TBT agreement, holding that the EU Seal Regime was a inequitable measure as it was intended to provide an advantage for seal products reaped by Greenland's Inuit groups over Canadian Inuit groups from the means this measure was undertaken. ${ }^{92}$ Specifically, the EU Seal Regime allowed the sale of seal products if those products are: (i) originated from hunts conducted by indigenous societies; (ii) originated from hunts that were undertaken for the sustainable administration of marine resources; or (iii) individually

88 Ibid.

89 Appellate Body Report, 'United States - Measures Affecting the Cross-Border Supply of Gambling and Betting Services' (WT/ DS285/AB/R, 7 April 2005) para 34

90 Ibid.

91 Ibid.

92 Appellate Body Report, 'European Communities Measures Prohibiting the Importation and Marketing of Seal Products (WT/DS400/AB/R, WT/DS401/AB/R, 22 May 2014) para 44.

93 Ibid.

94 Ibid. imported into the EU by tourists. ${ }^{93}$ In the final report, the $A B$ ruled that the EU Seal Regime destructively impacted the circumstances of competition for Norwegian and Canadian seal products when compared to Greenlandic seal products. ${ }^{94}$

\section{2) Protective Measures by Using Cultural Concern}

Beside imposing public morals exception, some WTO member states also employ cultural concern for justifying their measures ${ }^{95}$ although some of them fall within the range of 'inefficient protectionism'. ${ }^{96}$ Article XX (f) denotes how the exception also covered measures for safeguarding what has been categorized as nationwide assets of artistic, outstanding or archeologically value. ${ }^{97}$ Similar to public morals exception, the cultural concern must not be 'arbitrary or unjustifiable discrimination' between member states wherein the comparable circumstances triumph, or a 'disguised restriction' on international trade. ${ }^{98}$

The typical of cultural-related measures is the restrictions of market access, particularly to safeguard what member states have assumed as cultural goods and services. Spain and Mexico and Spain undertook screen quotas for movies to restrict the existence of foreign movies in their areas. ${ }^{99}$ Through its state-owned corporations, China activated screen publications, such as newspapers and books, video and audio and

95 I Gusti Ngurah Parikesit Widiatedja, 'Cultural Concern under Trade and Investment Agreements: Does it Really Work?' (2018) 5(2) Brawijaya Law Journal 173.

96 Krista Boryskavich, above n 16.

97 GATT 1947, above n 25, art XX (f)

98 Ibid art XX.

99 Christoph Beat Graber, 'Audio-visual Media and the Law of the WTO' in Christoph Beat Graber, Michael Girsberger and Mira Nenova (eds.) Free Trade versus Cultural Diversity: WTO Negotiations in the Field of Audiovisual (Schulthess, 2004) 15, 29. 
products as a tool of forestalling those products will not oppose with China's cultural values. ${ }^{100}$ Lately, China even undertook the control of internet through selecting and blocking procedure, and introducing what has been known as selfcensorship by internet users through supervision and punitive sanctions. ${ }^{101}$ Some member states also conducted precautionary measures to guard what they have regarded as cultural tradition. Benin ${ }^{102}$ and Haiti ${ }^{103}$ controlled the importation of alcohol; Israel prohibited importation of all non-Kosher meat products; 104 Brunei restricted importation in certain meat foods; ${ }^{105}$ and Qatar banned pork products' importation. ${ }^{106}$

Under the WTO mechanism, a member states may impose a restriction or discriminatory measures concerning cultural products for encouraging local value or to protect its producers. ${ }^{107}$ The range of cultural value of a particular product may cover not only the nature of product, or who make it, but also how it is created or consumed or how it impacts local identity. ${ }^{108}$ Nevertheless, as

100 See Panel Report, 'China - Measures Affecting Trading Rights and Distribution Services for Certain Publications and Audiovisual Entertainment Products' (WT/DS363/R, 12 August 2009) [4.113-4.120]

101 Quynh-Dan Nguyen, 'Error: Essay not Found: Comparing Censorship in China and South Korea (2016) 3(1) Brawijaya Law Journal 17, 20.

102 WTO Secretariat, Report of the WTO Secretariat on the Trade Policy Review of Benin, WT/TPR/S/131 (24 May 2004) [42].

103 WTO Secretariat, Report of the WTO Secretariat on the Trade Policy Review of Haiti, WT/TPR/S/99 (7 October 2003) [41].

104 WTO Secretariat, Report of the WTO Secretariat on the Trade Policy Review of Israel, WT/TPR/S/58 (13 August 1999) [24].

105 WTO Secretariat, Report of the WTO Secretariat on the Trade Policy Review of Brunei, WT/TPR/S/84 (27 April 2001) [43].

106 WTO Secretariat, Report of the WTO Secretariat on the Trade Policy Review of Qatar, WT/TPR/S/144 ( 24 January 2005) [26].

107 Tomer Broude, "Taking "Trade and Culture" Seriously: Geographical Indications and Cultural the following cases show, the Panel and the Appellate Body are success to limit the capacity of the WTO member states to execute measures for shielding local cultural products. $^{109}$

In Japan - Leather II (US), a Japanese regulation required leather importers to obtain import licenses, and to obey with import quotas ${ }^{110}$ in order to secure the jobs ofthe Dowa People, an indigenous groups. ${ }^{111}$ Japan claimed that the people of Dowa were in a lower economic and cultural status because of class system's discrimination. ${ }^{112}$ Nevertheless, the panel annulled Japan's measure as it had impaired or nullified benefits to other member states that was the US. ${ }^{113}$ Also, in Japan Alcoholic Beverages II, Japan asserted its lower taxes on 'shochu'compare to cognac, whiskey, and white spirits, ${ }^{114}$ denoting that the consumers of Japanese culturally considered shochu as dissimilar from those alcohol drinks, and consumed it in different methods. ${ }^{115}$ The Panel and Appellate Body then banned this measure as it fell within the

Protection in WTO Law' (2005) 26(4) University of Pennsylvania Journal of International Economic Law 623, 638.

108 Tania Voon, Cultural Products and the World Trade Organization (Cambridge University Press, 2007) 11

109 See Ivan Bernier, 'Trade and Culture' in Patrick FJ Macrory, Arthur E Appleton, and Michael G Plummer (eds.) The World Trade Organization: Legal, Economic and Political Analysis (Springer, 2005), 790.

110 Panel Report, Japanese Measures on Imports of Leather, L/5623 - 31S/94 (15/16 May 1984) [8] ('Japan-Leather II Panel Report')

111 Ibid [17]-[18].

112 Ibid [21]-[22].

113 Ibid [44].

114 Appellate Body Report, 'Japan - Taxes on Alcoholic Beverages' (WT/DS8/AB/R,1 November 1996) 17.

115 Panel Report, 'Japan - Taxes on Alcoholic Beverages' (WT/DS8/R, WT/DS10/R, WT/DS11/R, 1 November 1996) [4.54]. 
range of 'internal taxation', that was inconsistent with GATT Article III:2. ${ }^{116}$

In China - Audiovisual, through its state-owned companies, China screened publications of books, newspapers, video and audio, such as games, CDs, and DVDs. ${ }^{117}$ China argued that its mechanism was salient as a precautionary measure for confirming that those products did not contain any pornography or violence resources that conflicted China's cultural tradition. ${ }^{118}$ Both the Panel and the Appellate Body disagreed this measure as it led discriminatory conducts in which China stipulated the trade of importing publications must be operated by entirely State-owned businesses, and invalidated foreign businesses from being allowed as publication importers. As a result, this measure was beyond the range of general exception under GATT Article XX. ${ }^{119}$

In EC-Seal Products, the EU banned the importation and promotion of seal products to support the EU's moral anxieties concerning seals' prosperity. ${ }^{120}$ Canada contested this measure wherein sealing was a salient cultural tradition for its indigenous Inuit societies. ${ }^{121}$ The outcome of this measure discriminatory profited seal products gained by Greenland's Inuit societies over Canadian Inuit societies (that still applied cultural tradition) from the method this measure was commenced. ${ }^{122}$ In the final report, the Appellate Body held that the EU Seal Administration was unlawful because it had been implemented in a

\footnotetext{
116 Appellate Body Report, above n 111, 32.

117 Panel Report, 'China - Measures Affecting Trading Rights and Distribution Services for Certain Publications and Audiovisual Entertainment Products'(WT/DS363/R, 12 August 2009) [4.114].

118 Ibid [4.113-4.120].

119 Ibid [4.113-4.120].
}

discriminatory measure following GATT Article XX. ${ }^{123}$

\section{CONCLUSION}

The existence of inequality and poverty in some countries doubted the contribution of the WTO, criticizing its vision on trade liberalization. The overwhelming spirit of national interest has put WTO negotiations in deadlock. Besides, some WTO member states impose discriminatory and protective measure for the sake of national interest. Given its role for enforcing the commitments agreed under trade negotiations, the DSM is crucial to save the future of WTO. The DSM WTO has adjudicated 405 cases, making it as the most productive of all international DSM. This paper argues that the supremacy of the DSM WTO has ensured the future of WTO by looking at two parameters. Firstly, it analyses the character of the of DSM WTO where it falls within the scope of a legalcharacter with high level of legalism. It reflects through the existence of $\mathrm{AB}$ that has a functional and administrative autonomy. The AB also has an 'inherent powers', enabling it to freely manage the legal proceedings to the degree necessary to accomplish their adjudicative role. Next, by looking at the decision of the Panel and the Appellate Body, the DSM WTO has effectively controlled the overwhelming spirit of national interest. This decision has prevented member states to impose discriminatory measures by imposing public morals exception. Equally important, the DSM WTO is also able to show its

\footnotetext{
120 Appellate Body Report, above n 90, 24.

${ }^{121}$ Panel Report, 'European Communities - Measures Prohibiting the Importation and Marketing of Seal Products'(WTO Docs WT/DS400/R, WT/DS401R, 25 November 2013) [7.303-315].

122 Ibid [7.460].

123 Appellate Body Report, above n 90, 27.
} 
supremacy by limiting the capacity of the WTO member states to execute measures for protecting cultural concern. ${ }^{124}$

\section{REFERENCES}

\section{Books}

Alter, Karen J, The New Terrain of International Law: Courts, Politics, Rights (Princeton University Press, 2014).

Bartels, Lorand and Ortino, Federico (eds), Regional Trade Agreements and the WTO Legal System (Oxford University Press, 2006).

Bossche, Peter Van den, The Law and Policy of the World Trade Organization (Cambridge University Press, 2010)

Guzman, Andrew T. and Joost H.B. Pauwelyn, International Trade Law (Wolters Kluwer, $2^{\text {nd }}$ ed., 2012)

Hudec, Robert E, The GATT Legal System and World Trade Diplomacy (Praeger, 1975).

Islam, M. Rafiqul, International Trade Law of the WTO (Oxford University Press, 2006).

Jackson, John H, The World Trading System: Law and Policy of International Economic Relations (MIT Press, 1997).

Jayasuria, Sisiria, Mac Laren, Donald and Magee, Gary (eds), Negotiating a Preferential Trading Agreement: Issues, Constraints and Practical Options (Edward Elgar, 2009)

Johns, Leslie, Strengthening International Courts: The Hidden Costs of Legalization (University of Michigan Press, 2015)

\footnotetext{
124 See Ivan Bernier, 'Trade and Culture' in Patrick FJ Macrory, Arthur E Appleton, and Michael G Plummer (eds.) The World Trade Organization:
}

Lindblad, Thomas, 'The Political Economy of Recovery in Indonesia' in Jolle Demmers (etal), Good Governance in the Era of Global Neoliberalism (Taylor and Francis, 2004)

Lee, Yong-Shik, Gary N. Horlick, Won-Mog Choi and Tomer Broude (eds), Law and Development Perspective on International Trade Law: The Law and Development Institute (Cambridge University Press 2011).

Matsushita, Mitsuo (et al), The World Trade Organization: Law, Practice, and Policy (Oxford University Press $3^{\text {rd }}$ ed, 2003).

Molnar, Margit and Lesher, Molly, 'Indonesia' in Organization for Economic Cooperation and Development, Globalisation and Emerging Economies: Brazil, Russia, India, Indonesia, China, and South Africa (OECD, 2008).

Stiglitz, Joseph, 'Addressing Developing Country Priorities and Needs in the Millennium Round' in Roger B Porter and Pierre Sauve (eds), Seattle, the WTO and the Future of the Multilateral Trading System (Harvard University Press, 2000).

The Organization for Economic Cooperation and Development, Special Focus: Inequality in Emerging Economies (EEs) (OECD, 2011).

United Nations Development Programme, Human Development Report 2015 (United Nations, 2015).

Voon, Tania, Cultural Products and the World Trade Organization (Cambridge University Press, 2007).

Widiatedja, I Gusti Ngurah Parikesit, Kebijakan Liberalisasi Pariwisata:

Legal, Economic and Political Analysis (Springer, 2005), 790. 
Konstruksi Konsep, Ragam Masalah, dan Alternatif Solusi (Udayana University Press, 2011)

World Bank, The World Bank Group A to Z (World Bank, 2016).

World Trade Organisation Secretariat, World Trade Report 2007: Six Decades of Multilateral Co-operation - What Have We Learned? (WTO, 2007).

\section{Journal Articles}

Ahearn, Raymond J. 'Europe: Rising Economic Nationalism?' (CRS Report for Congress, 2006) $<$ http://research.policyarchive.org/437 8.pdf $>$.

Busch, Marc L. 'Democracy, Consultation, and the Paneling of Disputes under GATT' (2000) 44(4) The Journal of Conflict Resolution.

Broude, Tomer, 'Taking "Trade and Culture" Seriously: Geographical Indications and Cultural Protection in WTO Law' (2005) 26(4) University of Pennsylvania Journal of International Economic Law.

Bown, Chad P., 'Participation in WTO Dispute Settlement: Complainants, Interested Parties and Free Riders' (2005) 19(2) The World Bank Economic Review.

Boryskavich, Krista and Bowler, Aaron, 'Hollywood North: Tax Incentives and the Film Industry in Canada' (2002) 2 Asper Review of International Business and Trade Law.

Hyeran, J and Hyun Namgung, 'Dispute Settlement Mechanisms in Preferential Trade Agreements: Democracy, Boilerplates, and the Multilateral Trade Regime' (2012) 56(6) Journal of Conflict Resolution.

Johannesson, Louise and Mavroidis, Petros C., 'The WTO Dispute Settlement
System 1995-2016: A Data Set and Its Descriptive Statistics' (2017) 51(3) Journal of World Trade.

Lockhart, Johnand Voon, Tania, 'Review of the Appellate Review in the WTO Dispute Settlement System' (2005) 6 Melbourne Journal of International Law.

Mitchell, Andrew and Heaton, David, 'The Inherent Jurisdiction of WTO Tribunals: The SelectApplication of Public International Law Required by the Judicial Function' (2010) 31 Michigan Journal ofInternational Law. Munin, Nellie, 'The Evolution of Dispute Settlement Provisions in Israel's PTAs: Is There a Global Lesson?' (2010) 44(2) Journal of World Trade.

Nguyen, Quynh-Dan, 'Error: Essay not Found: Comparing Censorship in China and South Korea (2016) 3(1) Brawijaya Law Journal.

Porges, Amelia and Jackson, John H, 'The WTO and the New Dispute Settlement' (1994) 88 American Society of International Law.

Son, Nguyen Tan, 'Towards A Compatible Interaction between Dispute Settlement Under the WTO and Regional Trade Agreements' (2008) 5 Macquarie Journal of Business Law.

Voon, Tania, 'Evidentiary Challenges for Public Health Regulation in International Trade and Investment Law' (2015) 18 Journal of International Economic Law.

Widiatedja, I Gusti Ngurah Parikesit and I Gusti Ngurah Wairocana, 'The Rise of the Spirit of National Interest and the Existence of World Trade Organization Agreement: A Case Study of Indonesia' (2017) 4(2) Padjajaran Journal of Law. 
Widiatedja, I Gusti Ngurah Parikesit, 'Cultural Concern under Trade and Investment Agreements: Does it Really Work?' (2018) 5(2) Brawijaya Law Journal.

Widiatedja, I Gusti Ngurah Parikesit, Can Indonesia Invoke Public Morals Exception under the World Trade Organization (WTO) for Prohibiting Cross-Border Gambling? (2018) 7(2) Yustisia.

Wood, Adrian,'Openness and Wage Inequality in Developing Countries: The LatinAmerican Challenge to East Conventional Wisdom' (1997) 11(1)

World Bank Economic Review.

Zangl, Bernhard, 'Judicialization Matters! A

Comparison of Dispute Settlement under GATT and the WTO' (2008) 52(4) International Studies Quarterly.

Zimmermann, Thomas A., 'WTO Dispute Settlement at Ten: Evolution, Experiences \&Evaluation' (2005) 60The Swiss Review of International Economic Relations.

\section{International Law Materials}

Appellate Body Report, 'United States -

Measures Affecting the Production and Sale of Clove Cigarettes'

(WT/DS406/AB/R, adopted 24 April

2012, DSR 2012: XI).

Appellate Body Report, European Communities - Regime for the Importation, Sale and Distribution of Bananas (WT/DS27/AB/R, 25 September 1997).

Appellate Body Report, 'United States Import Prohibition of Certain Shrimp and Shrimp Products'

(WT/DS58/AB/R, 6 November 1998). Appellate Body Report, 'United States Measures Affecting the Cross-Border Supply of Gambling and Betting
Services' (WT/ DS285/AB/R, 7 April 2005).

Appellate Body Report, 'European Communities - Measures Prohibiting the Importation and Marketing of Seal Products (WT/DS400/AB/R, WT/DS401/AB/R, 22 May 2014).

Panel Report, 'China - Measures Affecting Trading Rights and Distribution Services for Certain Publications and Audiovisual Entertainment Products' (WT/DS363/R, 12 August 2009).

Panel Report, Japanese Measures on Imports of Leather, L/5623 - 31S/94 (15/16 May 1984).

Appellate Body Report, 'Japan - Taxes on Alcoholic Beverages' (WT/DS8/AB/R, 1 November 1996).

Panel Report, 'Japan - Taxes on Alcoholic Beverages' (WT/DS8/R, WT/DS10/R, WT/DS11/R, 1 November 1996).

Panel Report, 'China - Measures Affecting Trading Rights and Distribution Services for Certain Publications and Audiovisual Entertainment Products' (WT/DS363/R, 12 August 2009).

Panel Report, 'European Communities Measures Prohibiting Importation and Marketing of Seal Products' (WTO Docs WT/DS400/R, WT/DS401R, 25 November 2013).

\section{Internet Materials}

Ni Komang Erviani and Tassia Sipahutar, 'Anti-WTO activists make their move', The Jakarta Post (Online), 3 December 2013

<http://www.thejakartapost.com/news/ 2013/12/03/anti-wto-activists-maketheir-move.html>.

'World Trade Talks End in Collapse', BBC News (Online), 29 July 2008 $<$ http://news.bbc.co.uk/2/hi/business/7 531099.stm>. 
World Policy, 'Trump and Trade Yunus, Muhammad 'Nobel Lecture', 10 Bilateralism', World Policy (Online), December 2006 12 January 2017 $<$ http://nobelprize.org/nobel_prizes/pe <http://www.worldpolicy.org/blog/20 17/01/12/trump-and-tradeace/laureates/2006/yunus-lecturebilateralism>. en.html>. 